\title{
Phosphoinositol 3-kinase, a novel target molecule for the inhibitory effects of juglone on TPA-induced cell transformation
}

\author{
JUNG-IL CHAE $^{1 *}$, JIN HYOUNG CHO $^{1 *}$, DONG JOON KIM ${ }^{2}, \mathrm{KYUNG}$ AE LEE ${ }^{3}$, MOON-KYUN CHO $^{4}$, \\ HAE-SEON NAM ${ }^{4}$, KEE-MIN WOO ${ }^{3}$, SANG-HAN LEE $^{3,4}$ and JUNG-HYUN SHIM ${ }^{3}$ \\ ${ }^{1}$ Department of Oral Pharmacology, School of Dentistry and Institute of Oral Bioscience, BK21 Project, \\ Chonbuk National University, Jeonju, Republic of Korea; ${ }^{2}$ Hormel Institute, University of Minnesota, Austin, \\ MN 55912, USA; ${ }^{3}$ Department of Biochemistry, College of Medicine, ${ }^{4}$ Division of Molecular Cancer Research, \\ Soonchunhyang Medical Research Institute, Soonchunhyang University, Cheonan 330-090, Republic of Korea
}

Received January 29, 2012; Accepted March 12, 2012

DOI: $10.3892 / \mathrm{ijmm} .2012 .969$

\begin{abstract}
Juglone (5-hydroxy-1,4-naphthalenedione) from black walnut trees induces apoptosis and inhibits proliferation of various malignant cells. Here, we investigated whether juglone affects 12-O-tetradecanoylphorbol-13-acetate (TPA)-induced cell transformation through the phosphoinositol 3-kinase (PI3K) pathway. The results showed that TPA- and endothelial growth factor (EGF)-induced anchorage-independent colony formation were suppressed in a dose-dependent manner by treatment of JB6 CI41 mouse skin epidermal cells with juglone (2.5 and $5 \mu \mathrm{M}$ ). We demonstrated that juglone suppressed PI3K activity via direct binding to PI3K by sepharose 4B pulldown assay and western blot analysis. Juglone significantly suppressed TPA-induced protein kinase B (AKT) and c-Jun phosphorylation and c-fos activation, but not mitogen-activated protein-kinase kinase (MEK), extracellular signaling-regulated kinase (ERK) or $90 \mathrm{kDa}$ ribosomal protein S6 kinase (RSK) phosphorylation. Juglone significantly blocked activator protein-1 (AP-1) and cyclooxygenase-2 (COX-2) activation more than the PI3K inhibitors LY294002 and wortmannin. Overall, these results showed the anticancer efficacy of juglone targeting PI3K to prevent TPA-induced tumorigenesis.
\end{abstract}

\section{Introduction}

Juglone (5-hydroxy-1,4-naphthalenedione) is a quinone pigment that occurs naturally in the roots, leaves, nut-hulls, bark, and wood of walnut trees $(1,2)$. Juglone is a well-known

Correspondence to: Dr Jung-Hyun Shim, Department of Biochemistry, College of Medicine, Soonchunhyang University, Sang-Yong Dong, Seo-Buk Gu, Cheonan, Choongnam 330-090, Republic of Korea

E-mail: s1004jh@gmail.com

*Contributed equally

Key words: juglone, cell transformation, phosphoinositol 3-kinase, anti-protein kinase B, 12-O-tetradecanoylphorbol-13-acetate allelopathic agent that has differential effects on cell cycling and metabolism depending on the species, organ, and drug concentration (3). Juglone has therapeutic properties and is being used in commercial hair dyes (4-6). Although hair dyes are widely used, permanent hair dye colors are formed by an oxidative process involving arylamines, giving rise to concerns about the potential adverse health effects of long-term exposure, particularly cancer. Some aromatic amines in hair dyes are mutagenic in vitro (7) and carcinogenic in animals and humans $(8,9)$. Therefore, use of hair dyes has been suggested as a risk factor for several types of cancer (10).

Many types of cancer are closely connected with peptidyl prolyl isomerase (Pin1). Pin1 is significantly overexpressed in human cancer and plays a positive role in cell proliferation or transformation during oncogenesis $(11,12)$. More than 10 years ago, juglone, which is a Pin1 inhibitor (13), was used in several cancer cell studies (14-16). But, no reports are available about the molecular mechanism of juglone and its association with the antitumorigenesis effect in skin cancer cell development.

Development of cancer cells is associated with the phosphoinositol 3-kinase (PI3K) pathway $(17,18)$ which mediates signal transduction and gene expression effects that contribute to tumorigenesis (19). Actually, PI3K plays a major role not only in tumor growth but also in the potential response of a tumor to cancer treatment (20). Moreover, previous studies have demonstrated that PI3K is required for 12-O-tetradecanoylphorbol-13-acetate (TPA) or endothelial growth factor (EGF)-induced cell transformation $(1,21)$. Therefore, studies about the molecular influence of juglone on PI3K signaling in skin cancer cell development are needed.

Here, we studied the molecular mechanism of juglone as a potential target for tumor suppression by studying the PI3K pathway during TPA- or EGF-induced JB6 CI41 mouse skin epidermal cell transformation. The goal of this research was to develop chemotherapy drugs against malignant cancer cells.

\section{Materials and methods}

Materials. Anti-protein kinase B (AKT), anti-phospho-AKT (Ser473), anti-phospho-c-Jun (Ser73), anti-c-Jun, anti-c-fos, anti-mitogen-activated protein kinase kinase (MEK), and 
anti-phospho-MEK (Ser217/221), anti-extracellular signalingregulated kinase(ERK), anti-phospho-ERKs (Thr202/Tyr204), anti-RSK, and anti-phospho-p90RSK (Ser380) were purchased from Cell Signaling Technology, Inc. (Charlottesville, VA, USA). The PI3K active protein was purchased from Upstate Biotechnology (Lake Placid, NY, USA). Anti- $\beta$-actin, juglone, LY294002, wortmannin, and TPA were purchased from Sigma-Aldrich (St. Louis, MO, USA). Cell culture medium and other supplements were purchased from Life Technologies (Rockville, MD, USA). CNBr-Sepharose 4B and $\left[\gamma^{-32} \mathrm{P}\right]$ ATP were obtained from GE Healthcare (Piscataway, NJ, USA). The CellTiter 96 AQueous One Solution Cell Proliferation Assay kit and the luciferase assay substrate were obtained from Promega (Madison, WI, USA).

Cell culture. JB6 CI41 cells were obtained from the American Type Culture Collection (Manassas, VA, USA). Cells were maintained in Eagle's minimum essential medium (MEM) supplemented with 5\% fetal bovine serum (FBS), $2 \mathrm{mM}$ L-glutamine and $25 \mu \mathrm{g} / \mathrm{ml}$ gentamicin at $37^{\circ} \mathrm{C}$ in a $5 \% \mathrm{CO}_{2}$ incubator. The JB6 CI41 cell line was stably transfected with activator protein-1 (AP-1) and cyclooxygenase-2 (COX-2) luciferase reporter plasmids obtained from Dr Zigang Dong (The Hormel Institute, University of Minnesota, Austin, MN) (22).

MTS assay. The effect of juglone on cell viability was estimated using the CellTiter 96 AQueous One Solution Cell Proliferation Assay kit following the manufacturer's instructions. Cells were seeded in a 96-well plate for $24 \mathrm{~h}$ and then incubated with different concentrations of juglone $(1,2.5$ and $5 \mu \mathrm{M}$ ) for 24 and $48 \mathrm{~h}$. The assay solution was added to each well for $3 \mathrm{~h}$ at $37^{\circ} \mathrm{C}$ in $5 \% \mathrm{CO}_{2}$, and absorbance at $490 \mathrm{~nm}$ was recorded using the GloMax-Multi Microplate Multimode Reader (Promega).

Anchorage-independent cell growth assay. Cells $\left(8 \times 10^{3}\right)$ were exposed to TPA or EGF with or without various concentrations of juglone in $1 \mathrm{ml}$ of $0.33 \%$ basal medium Eagle's (BME) agar over $3 \mathrm{ml}$ of $0.5 \%$ BME agar containing $10 \%$ FBS. The cultures were maintained at $37^{\circ} \mathrm{C}$ in a $5 \% \mathrm{CO}_{2}$ incubator for 12 days and then the cell colonies were automatically counted using a microscope and the Image-Pro plus software program v.4 (Media Cybernetics, Silver Spring, MD, USA).

In vitro juglone-Sepharose $4 B$ pull-down assay. This method has been described previously $(23,24)$. Briefly, PI3K active protein $(2 \mu \mathrm{g})$ was reacted with Sepharose 4B beads or jugloneSepharose 4B beads in reaction buffer [50 mM Tris, $\mathrm{pH} 7.5$, $5 \mathrm{mM}$ ethylenediaminetetraacetic acid (EDTA), $150 \mathrm{mM} \mathrm{NaCl}$, $1 \mathrm{mM}$ dithiothreitol (DTT), $0.01 \%$ Nonidet P-40, $2 \mu \mathrm{g} / \mathrm{ml}$ bovine serum albumin, $0.02 \mathrm{mM}$ phenylmethylsulfonyl fluoride (PMSF), and $1 \mathrm{X}$ proteinase inhibitor cocktail]. After overnight incubation with gently rocking at $4^{\circ} \mathrm{C}$, the beads were washed five times with washing buffer $(50 \mathrm{mM}$ Tris, $\mathrm{pH} 7.5,5 \mathrm{mM}$ EDTA, $150 \mathrm{mM} \mathrm{NaCl}, 1 \mathrm{mM}$ DTT, $0.01 \%$ Nonidet P-40 and $0.02 \mathrm{mM}$ PMSF) and proteins bound to the beads were analyzed by western blot analysis.

Phosphoinositide 3-kinase activity assay. Kinase assays were conducted as reported previously (23). Briefly, active PI3K
A<smiles>O=C1C=CC(=O)c2c(O)cccc21</smiles>

Juglone (5-hydroxy-1,4-naphthalenedione)

B

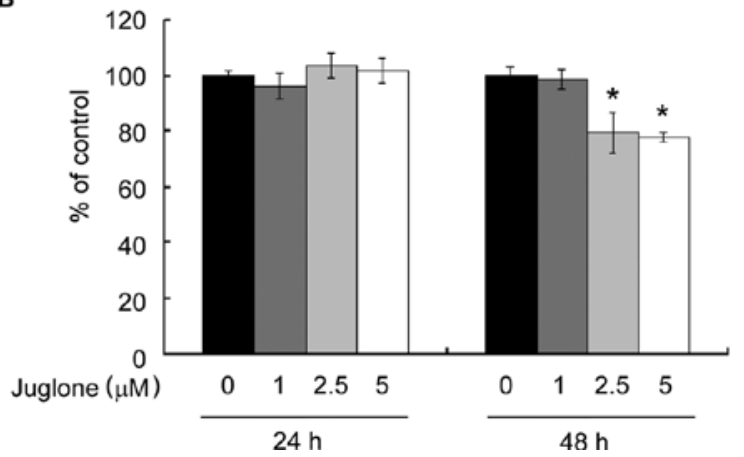

Figure 1. Effects of juglone on cell viability in JB6 CI41 mouse skin epidermal cells. (A) The chemical structure of juglone. (B) Cell viability effect of juglone on JB6 CI41 cells. JB6 CI41 cells $\left(1 \times 10^{3}\right.$ cells $\left./ 200 \mu 1\right)$ were treated with juglone $(1,2.5$ and $5 \mu \mathrm{M})$ in $5 \%$ FBS-MEM for various times. Cell viability was determined using the CellTiter 96 AQueous One Solution Cell Proliferation Assay kit. Data are mean \pm SD of three independent experiments performed in triplicate. The asterisk indicates a significant difference compared with the negative control $(\mathrm{P}<0.05)$.

protein $(100 \mathrm{ng})$ was incubated with juglone for $10 \mathrm{~min}$ at $30^{\circ} \mathrm{C}$. The mixtures were incubated with phosphatidylinositol (PI) $(10 \mu \mathrm{g})$ (Avanti Polar Lipids, Alabaster, AL, USA) for $5 \mathrm{~min}$. Subsequently, the mixture was incubated at room temperature in reaction buffer [100 $\mathrm{mM}$ HEPES (pH 7.6), $50 \mathrm{mM} \mathrm{MgCl}_{2}$, $250 \mu \mathrm{M}$-ATP $]$ containing $10 \mu \mathrm{Ci}$ of $\left[\gamma^{-32} \mathrm{P}\right]-\mathrm{ATP}$ for $10 \mathrm{~min}$ at $30^{\circ} \mathrm{C}$. The reaction was terminated by adding $15 \mu \mathrm{l}$ of $4 \mathrm{M} \mathrm{HCl}$ and $130 \mu \mathrm{l}$ chloroform-methanol $(1: 1, \mathrm{v} / \mathrm{v})$. A $30 \mu \mathrm{l}$ aliquot of the lower chloroform phase was spotted onto a $1 \%$ potassium oxalate-coated silica gel plate that was previously activated for $1 \mathrm{~h}$ at $110^{\circ} \mathrm{C}$. The resulting ${ }^{32} \mathrm{P}$-labeled phosphatidylinositol3-phosphate (PI3P) was separated by thin-layer chromatography and radiolabeled spots were analyzed by autoradiography.

Western blot analysis. After the cells were seeded in $10-\mathrm{cm}$ dishes for $48 \mathrm{~h}$, they were starved in $0.1 \%$ FBS/MEM medium for $24 \mathrm{~h}$. Cells were pre-treated with juglone $(1,2.5$ and $5 \mu \mathrm{M})$ for $1 \mathrm{~h}$ before they were exposed to TPA $(20 \mathrm{ng} / \mathrm{ml})$ or EGF $(10 \mathrm{ng} / \mathrm{ml})$ for an additional $24 \mathrm{~h}$. The harvested cells were disrupted, and protein supernatant fractions were subjected to SDS-PAGE and then transferred to membranes and blocked with $5 \%$ skim milk followed by hybridization with specific antibodies. Proteins were exposed to horseradish peroxidase (HRP)-conjugated secondary antibody and visualized by Amersham ECL Plus Western Blotting Detection reagents (GE Healthcare).

Luciferase assay to determine AP-1 or COX-2 transactivation. AP-1 or COX-2 luciferase reporter JB6 CI41 cells were cultured in a 24 -well plate for $24 \mathrm{~h}$. Then, they were starved 
A
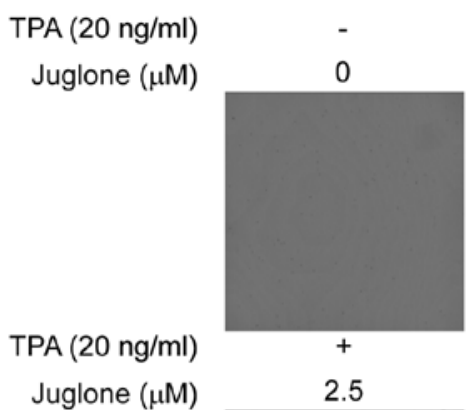

2.5
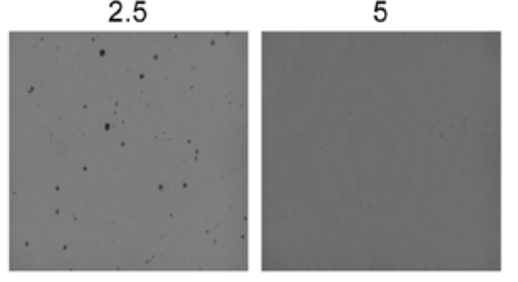

B $\operatorname{EGF}(10 \mathrm{ng} / \mathrm{ml})$

Juglone $(\mu \mathrm{M})$

EGF $(10 \mathrm{ng} / \mathrm{ml})$
Juglone $(\mu \mathrm{M})$
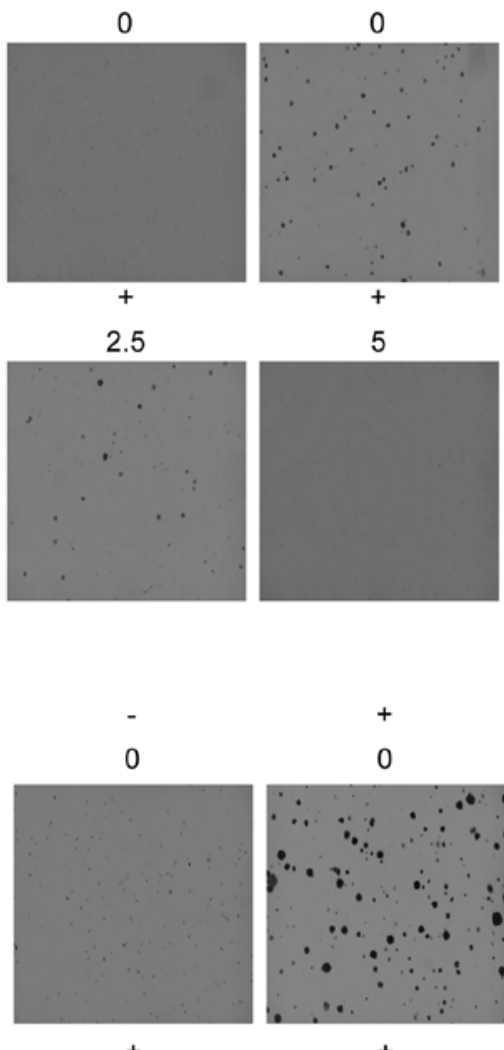

$+$

\section{.}
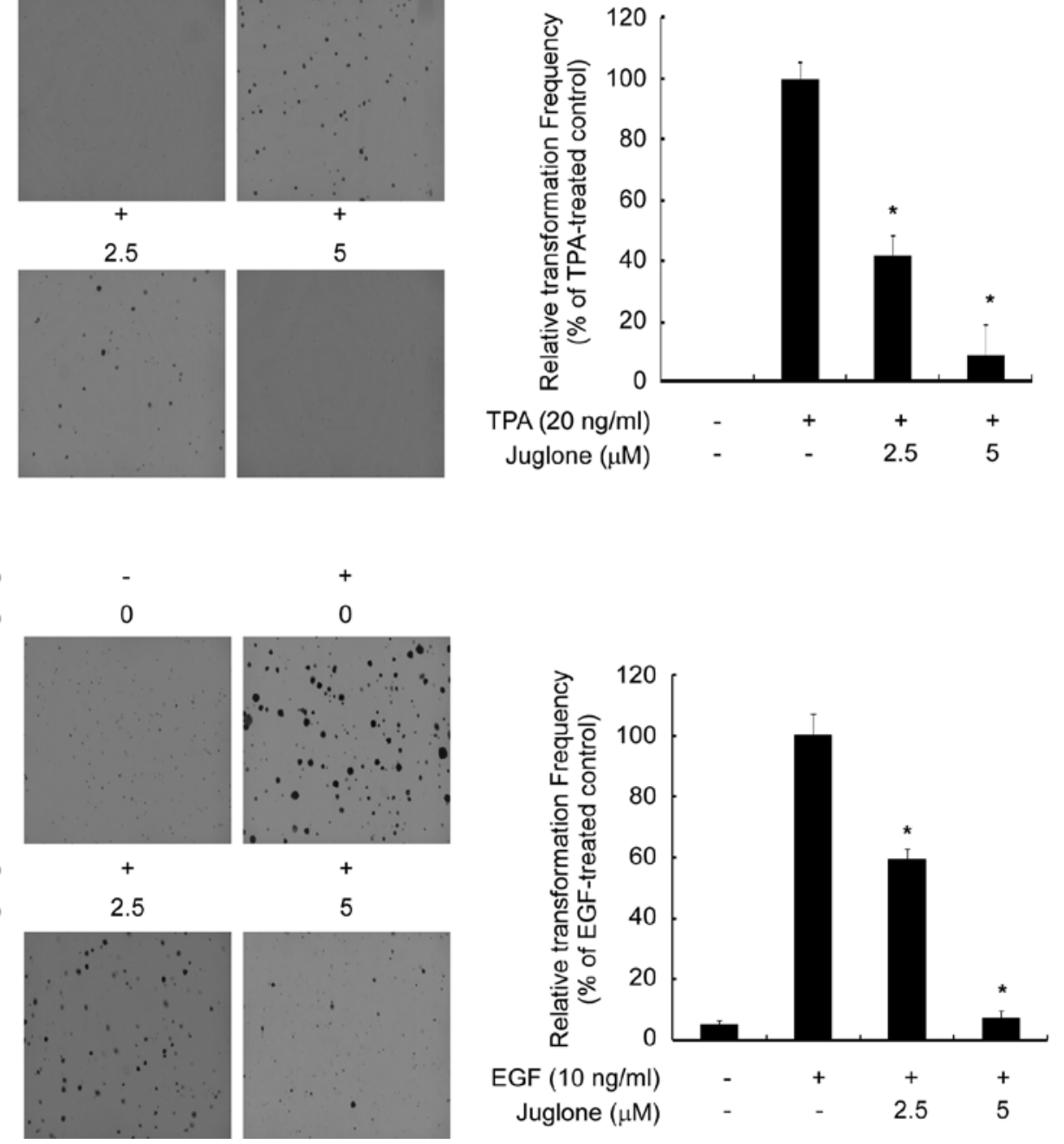

Figure 2. The effect of juglone on TPA- or EGF-induced anchorage-independent colony formation in JB6 CI41 cells. JB6 CI41 cells were treated as described in Materials and methods and cell colonies were counted after 12 days. Then, the cell colonies were automatically counted by a computerized microscope system. ${ }^{*} \mathrm{P}<0.001$, significant difference between groups treated with TPA or EGF and the group treated with TPA or EGF and juglone. Data are mean \pm SD of three independent experiments in triplicates.

in $0.1 \% \mathrm{FBS} / \mathrm{MEM}$ medium for an additional $24 \mathrm{~h}$ in a $5 \%$ $\mathrm{CO}_{2}$ incubator. The cells were treated for $1 \mathrm{~h}$ with juglone or a PI3K inhibitor (LY294002 or wortmannin) and then exposed to TPA $(20 \mathrm{ng} / \mathrm{ml})$ or EGF $(10 \mathrm{ng} / \mathrm{ml})$ and harvested after $24 \mathrm{~h}$. Luciferase activity was assessed using the Luciferase Assay kit as recommended by the manufacturer (Promega). Cells were disrupted with $200 \mu 1$ of lysis buffer, and luciferase activity was measured using Luminoskan Ascent (Thermo Electron, Helsinki, Finland).

Statistical analysis. Data are reported as mean \pm SD of at least three independent experiments performed in triplicate. Data were analyzed for statistical significance using a one-way analysis of variance. A value of $\mathrm{P}<0.05$ was considered to denote significant differences.

\section{Results}

Effect of juglone on JB6 CI41 cell viability. Recent studies have demonstrated that juglone induces cell death in skin cancer
(B16F1, mouse melanoma cells) (25). The viability effects of juglone on JB6 CI41 mouse skin epidermal cells during 24 and $48 \mathrm{~h}$ were determined by the MTS assay at various concentrations $(1,2.5$ and $5 \mu \mathrm{M})$. Juglone had no affect on JB6 CI41 cell toxicity at any dose or time point assessed (Fig. 1B).

Juglone significantly suppresses TPA- or EGF-induced cell transformation. JB6 CI41 cells are useful for studying the molecular mechanisms of tumor promotion and antitumor agents (26). We examined the inhibitory activities of juglone on TPA- or EGF-induced neoplastic JB6 CI41 cell transformation. Treatment with juglone $(2.5$ and $5 \mu \mathrm{M})$ significantly inhibited $50-90 \%$ of neoplastic transformation as compared to TPA- or EGF-induced transformation without juglone. These results indicate that juglone is a potent inhibitor of TPA- or EGF-induced transformation in JB6 CI41 cells (Fig. 2).

Phosphoinositide 3-kinase is a potential target of juglone. The $\mathrm{PI} 3 \mathrm{~K}$ pathway is one of the most important pathways in cancer 
A PI3K, active (100 ng) - ++++

$\operatorname{PIP}(10 \mathrm{ng})++\quad++$

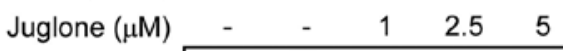

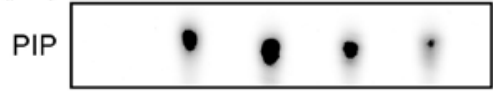

B

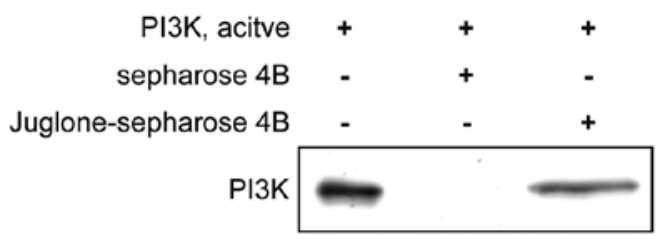

Figure 3 . The effect of juglone on PI3K activity in vitro. (A) Juglone strongly inhibited PI3K activity. Active PI3K protein $(100 \mathrm{ng})$ was pre-incubated with juglone for $10 \mathrm{~min}$ at $30^{\circ} \mathrm{C}$. The resulting ${ }^{32} \mathrm{P}$-labelled $\mathrm{PI} 3 \mathrm{P}$ was visualized as described in Materials and methods. (B) Juglone directly bound with PI3K in vitro. The in vitro binding of juglone with active PI $3 \mathrm{~K}$ protein was confirmed by a pull-down assay using juglone-Sepharose $4 \mathrm{~B}$ beads and subsequent western blot analysis.

A

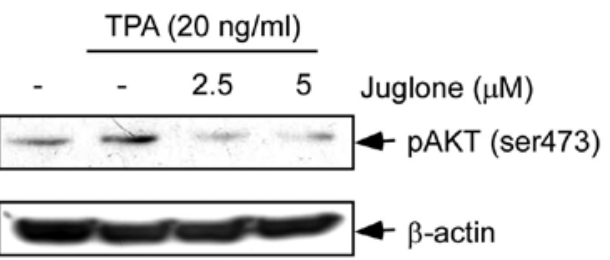

B

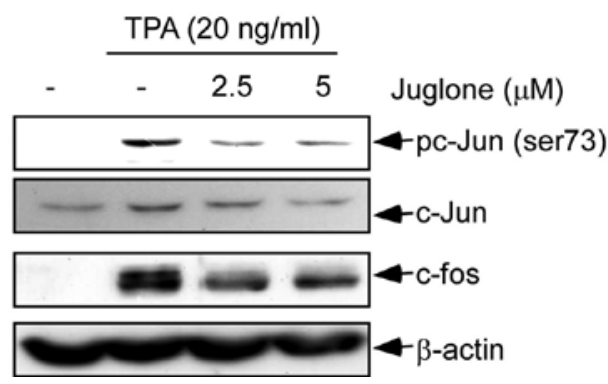

Figure 4. The effect of juglone on TPA-induced AKT, c-Jun, and c-fos activation in JB6 CI41 cells. Juglone inhibited TPA-induced (A) AKT, c-Jun, and (B) c-fos activation. JB6 CI41 cells were treated with juglone at 2.5 and $5 \mu \mathrm{M}$ for $1 \mathrm{~h}$ before being treated with TPA $(20 \mathrm{ng} / \mathrm{ml})$ and harvested after $30 \mathrm{~min}$. The protein expression levels of phosphorylated and total AKT, c-Jun and c-fos proteins were analyzed by western blot analysis. Equal loading of proteins was determined by incubating the same membrane with anti- $\beta$-actin antibody.

metabolism and growth (27). Moreover, previous studies have demonstrated that PI3K is required for TPA- or EGF-induced cell transformation $(1,21)$. Therefore, we studied the effect of juglone on PI3K activity to investigate the molecular target of juglone. The PI3K assay data indicated that juglone $(5 \mu \mathrm{M})$ significantly inhibited PI3K activities in vitro (Fig. 3A). A direct interaction of juglone-Sepharose 4B beads with active PI3K was demonstrated by the in vitro pull-down assay (Fig. 3B). Our results suggest that juglone strongly suppressed PI3K activity by directly binding to PI3K.

Juglone blocks TPA-induced activation of AKT but not $M E K$. Our results indicate that juglone specifically binds with PI3K and subsequently inhibits PI3K activation. Therefore, we investigated the influence of juglone on TPA-induced

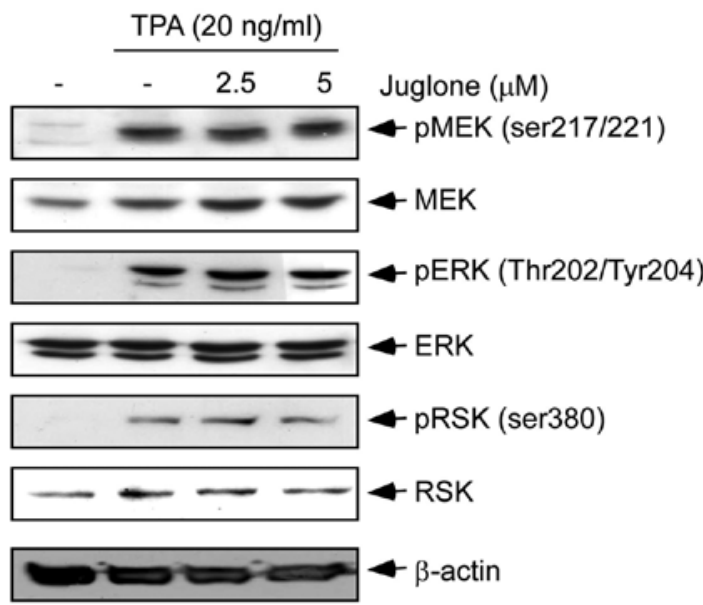

Figure 5. The effect of juglone on TPA-induced phosphorylation of MEK, ERK and RSK. JB6 CI41 cells were treated with juglone at various concentrations $(1,2.5$ and $5 \mu \mathrm{M})$ for $1 \mathrm{~h}$ and then exposed to $20 \mathrm{ng} / \mathrm{ml}$ TPA for $30 \mathrm{~min}$. The levels of phosphorylated and total MEK, ERK, and RSK protein detected by western blot analysis. Cellular extract ( $30 \mu \mathrm{g} / \mathrm{lane}$ ) was separated on a $10 \%$ SDS-PAGE gel using the indicated antibodies. Equal loading and protein transfer were confirmed with anti- $\beta$-actin antibody. Data are representative of three independent experiments.

activation of AKT. TPA-induced phosphorylation of AKT was almost inhibited by treatment with juglone $(2.5$ or $5 \mu \mathrm{M})$ (Fig. 4A). We examined the effect of juglone on the activation of several downstream kinases in JB6 CI41 cells. TPA-induced c-Jun and c-fos activation was significantly suppressed by juglone in a dose-dependent manner (Fig. 4B). Previous studies have indicated that the MEK signaling pathway is involved in TPA-induced JB6 CI41 cell transformation $(26,28)$. Therefore, we confirmed the influence of juglone on the MEK signaling pathway. TPA-induced phosphorylation of MEK was not inhibited by juglone. Moreover, juglone had no effect on TPA-induced phosphorylation of ERK and RSK, a downstream kinase of MEK (Fig. 5).

Juglone attenuates TPA- or EGF-induced transactivation of $A P-1$ and $C O X-2$. Multiple signal transduction pathways including AKT are activated by TPA $(29,30)$ or EGF (31) and increased AKT phosphorylation leads to AP-1 and COX-2 activation (32) which modulate carcinogenesis (33). Therefore, to determine whether the suppression of transformation by juglone involves inhibition of AP-1 and COX-2 activities, we measured AP-1 and COX-2 transactivation using JB6 CI41 cell lines stably transfected with an AP-1 or COX-2 luciferase plasmid. We determined that TPA-induced AP-1 or COX-2 activity was achieved using juglone compared with LY294002 or wortmannin. LY294002 inhibits PI3K by competing with ATP for its substrate binding site (34) and wortmannin also inhibits PI3K activity (35). The results showed that wortmannin $(5 \mu \mathrm{M})$ inhibited TPA- or EGF-induced AP-1 activity, whereas no significant inhibition was shown by COX-2 (Fig. 6). LY294002 (20 $\mu \mathrm{M})$ significantly suppressed the activity of TPA- or EGF-induced COX-2, but not for AP-1. Juglone inhibited TPA- or EGF-induced transactivation of either AP-1 or COX-2 in a dose-dependent manner. AP-1 activity is regulated at the level of c-Jun and c-fos gene transcription by protein-protein interactions and also through Jun and fos post-translational protein modifications (36-38). 
A

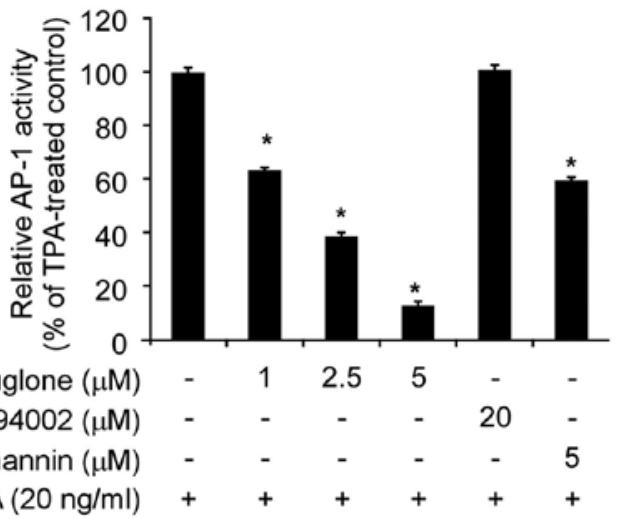

C

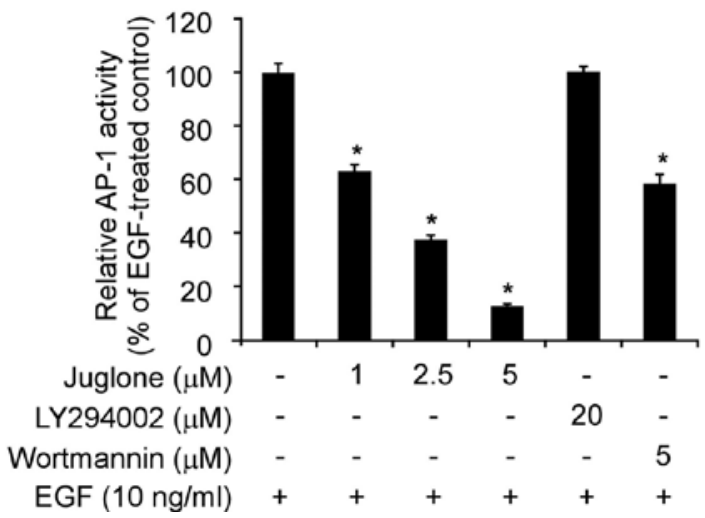

B

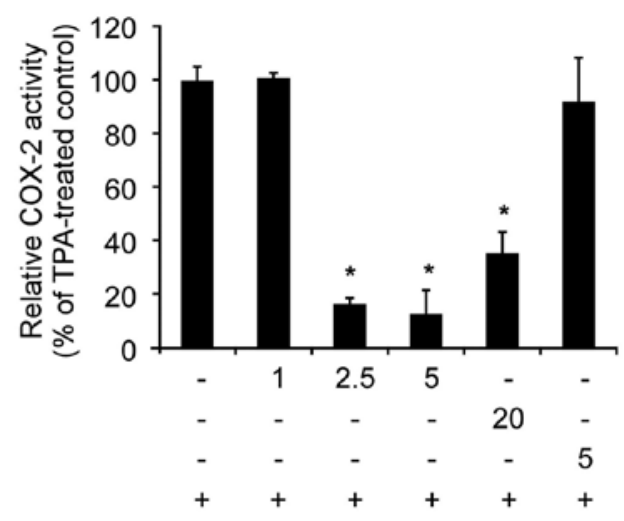

D

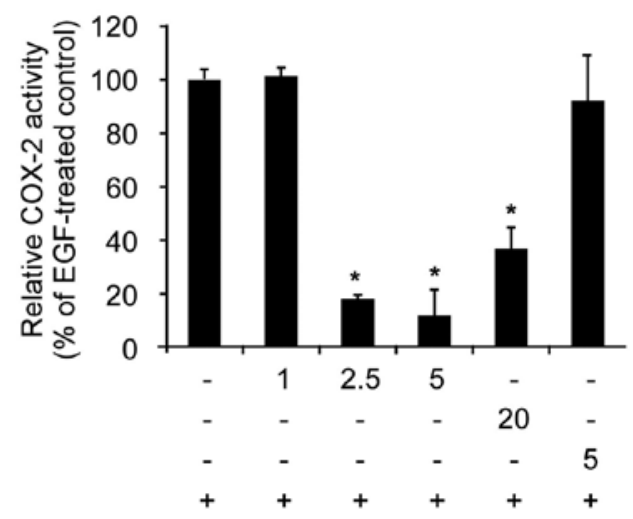

Figure 6. The effect of juglone on TPA- or EGF-induced AP-1 and COX-2 activation. The effect of juglone, LY294002 and wortmannin on (A) TPA- or (C) EGFinduced AP-1 and (B and D) COX-2 transactivation. Cells were seeded in 24-well plates for $24 \mathrm{~h}$ and then starved by culturing in $0.1 \%$ FBS-MEM for $24 \mathrm{~h}$. Cells were pre-treated with juglone, wortmannin, or LY294002 for $1 \mathrm{~h}$ and than incubated with TPA (20 ng/ml) or EGF (10 ng/ml) for $24 \mathrm{~h}$. Luciferase activity was measured, and AP-1 and COX-2 promoter activity was expressed as the percent inhibition relative to cells treated with TPA or EGF alone. Data are representative of triplicate samples from three independent experiments. "P<0.001, significant change relative to cells activated with TPA or EGF.

TPA-induced c-Jun and c-fos was inhibited by juglone (Fig. 4C). Juglone strongly suppressed TPA- or EGF-induced AP-1 and COX-2 luciferase activity compared with LY294002 and wortmannin by inhibiting c-Jun and c-fos.

\section{Discussion}

Juglone is one of the oldest known allelopathic compounds in the history of cultivation and is used as an active ingredient in herbal remedies and commercial dyes $(4,16)$ (Fig. 1A). Juglone is used extensively to overcome resistance to chemotherapeutic agents in cancer due to their cytotoxicity (39). For example, the bark, branches and exocarp of the immature green fruit of this medicinal plant have been used to treat gastric cancer, liver cancer, lung cancer and other types of cancer (40). Juglone is also a potent cytotoxic agent in vitro in human tumor cell lines, including human colon carcinoma (HCT-15) cells, human leukemia (HL-60) cells, and doxorubicin-resistant human leukemia (HL-60R) cells $(5,41)$. Therefore, juglone has been previously used for its therapeutic properties. Accumulated evidence suggests that juglone has chemopreventative or chemotherapeutic effects on various types of cancer.

In this study, we investigated the molecular mechanism of juglone as a potential target for tumor suppression. JB6 CI41 cells are useful for studying the molecular mechanisms of tumor promotion and antitumor agents (26). Therefore, we primarily determined the cell viability effects of juglone on the proliferation of JB6 CI41 cells using the MTS assay. We confirmed that juglone did not significantly inhibit JB6 CI41 cell growth in either a dose- or time-dependent manner (Fig. 1B). Next, we examined the inhibitory activities of juglone on TPA- or EGF-induced neoplastic JB6 CI41 cell transformation, as both TPA and EGF are well-known tumor promotion agents used to study malignant cell transformation in cell and animal models of cancer (42). Approximately $50-90 \%$ of TPAor EGF-induced cell transformation was inhibited by juglone as compared to neoplastic transformation without juglone (Fig. 2). These results suggest that juglone plays an important role as an antitumor agent in TPA- or EGF-induced tumorigenesis. Thus, we examined a juglone pull-down assay to identify juglone molecular targets in tumorigenesis and confirmed that juglone specifically binds with PI3K (Fig. 3B). Moreover, the PI3K activity assay results showed that juglone $(5 \mu \mathrm{M})$ significantly inhibited PI3K activity in vitro (Fig. 3A), indicating that PI3K activity can be directly regulated by juglone treatment.

$\mathrm{PI} 3 \mathrm{~K}$ is a major signaling component downstream of many growth factor receptor tyrosine kinases and PI3K family members act as cellular sensors to relay mitogenic signals to internal cellular effectors (43). In particular, PI3K/AKT affects the expression of genes that contribute to tumorigenesis and is activated by many types of cellular stimuli and toxic insults (44). Previous studies have demonstrated that PI3K/AKT signaling is 
associated with the development of diseases, such as cancer (18). Actually, PI3K/AKT signaling plays a major role not only in tumor growth but also in the potential response of a tumor to cancer treatment (20). Therefore, we investigated the influence of juglone on TPA-induced activation of AKT, c-Jun, and c-fos, which are downstream PI3K/AKT signaling molecules. The results showed that juglone significantly inhibited TPA-induced phosphorylation of AKT (Fig. 4A) and phosphorylation of c-Jun and c-fos (Fig. 4B). However, TPA-induced phosphorylation of MEK, ERK and RSK, downstream ERK kinases were not inhibited (Fig. 5). These results suggest that juglone leads to a decrease in TPA-induced cell transformation by blocking the PI3K/AKT signaling by inhibiting c-Jun and c-fos. c-Jun and c-fos, which form dimeric complexes such as Jun-Jun or Jun-fos are components of the AP-1 family (45). AP-1 is a major eukaryotic transcription factor involved in regulating COX-2 expression (46-48) which plays an important role in tumorigenesis (49). According to a previous study, TPA-induced AP-1 transactivation and transformation in JB6 CI41 cells and JB6 CI41 cell promotion-sensitive cell transformation is induced by TPA (21). We determined whether TPA or EGF could induce AP-1 or COX-2 activity and promote TPA- or EGF-induced AP-1 or COX-2 activity in JB6 CI41 cells by exposing JB6 CI41 cells to TPA (20 ng/ml) or EGF (10 ng/ml) (Fig. 6). Additionally, juglone activity was compared to that of LY294002 and wortmannin, which are widely used specific PI3K inhibitors (50). Juglone significantly inhibited TPA- and EGF-induced AP-1 (Fig. 6A and C) and COX-2 (Fig. 6B and D) activity compared with that of LY294002 and wortmannin. These results indicate that enhancement of TPA-induced PI3K activity could be markedly blocked more by juglone than that of LY294002 or wortmannin.

In summary, juglone was effective in inhibiting the neoplastic transformation induced by TPA or EGF in JB6 CI41 cells. This inhibition was mediated primarily by blocking the PI3K/AKT signaling pathway and subsequent suppression of AP-1 and COX-2 activity. Juglone inhibited PI3K activity by directly binding with PI3K. Furthermore, juglone directly blocked TPA- or EGF-induced PI3K activation. Given the critical role of $\mathrm{PI} 3 \mathrm{~K}$ in carcinogenesis, these results suggest that $\mathrm{PI} 3 \mathrm{~K}$ is a potent molecular target of juglone and may provide the molecular basis to develop chemotherapeutic drugs that target cancerous cells. Additionally, juglone could be a useful chemical for industrial and medical products such as hair dyes, skin care balms, and anticancer foods.

\section{Acknowledgements}

This study was supported by the Basic Science Research program through the National Research Foundation Korea (NRF) funded by the Ministry of Education, Science and Technology (20110008463), and the Next-Generation BioGreen 21 Program (PJ008116062011), Rural Development Administration, Republic of Korea.

\section{References}

1. Varga Z, Bene L, Pieri C, Damjanovich S and Gaspar R Jr: The effect of juglone on the membrane potential and whole-cell $\mathrm{K}^{+}$ currents of human lymphocytes. Biochem Biophys Res Commun 218: 828-832, 1996.
2. Inbaraj JJ and Chignell CF: Cytotoxic action of juglone and plumbagin: a mechanistic study using $\mathrm{HaCaT}$ keratinocytes. Chem Res Toxicol 17: 55-62, 2004.

3. Chobot V and Hadacek F: Milieu-dependent pro- and antioxidant activity of juglone may explain linear and nonlinear effects on seedling development. J Chem Ecol 35: 383-390, 2009.

4. Erdemoglu N, Kupeli E and Yesilada E: Anti-inflammatory and antinociceptive activity assessment of plants used as remedy in Turkish folk medicine. J Ethnopharmacol 89: 123-129, 2003.

5. Segura-Aguilar J, Jonsson K, Tidefelt U and Paul C: The cytotoxic effects of 5-OH-1,4-naphthoquinone and 5,8-diOH1,4-naphthoquinone on doxorubicin-resistant human leukemia cells (HL-60). Leuk Res 16: 631-637, 1992.

6. Sugie S, Okamoto K, Rahman KM, et al: Inhibitory effects of plumbagin and juglone on azoxymethane-induced intestinal carcinogenesis in rats. Cancer Lett 127: 177-183, 1998.

7. Ames BN, Kammen HO and Yamasaki E: Hair dyes are mutagenic: identification of a variety of mutagenic ingredients. Proc Nat Acad Sci USA 72: 2423-2427, 1975.

8. Sontag JM: Carcinogenicity of substituted-benzenediamines (phenylenediamines) in rats and mice. J Natl Cancer Inst 66: 591-602, 1981.

9. Takkouche B, Etminan M and Montes-Martinez A: Personal use of hair dyes and risk of cancer: a meta-analysis. JAMA 293: 2516-2525, 2005.

10. Rollison DE, Helzlsouer KJ and Pinney SM: Personal hair dye use and cancer: a systematic literature review and evaluation of exposure assessment in studies published since 1992. J Toxicol Environ Health B Crit Rev 9: 413-439, 2006.

11. Han CY, Hien TT, Lim SC and Kang KW: Role of Pin1 in UVA-induced cell proliferation and malignant transformation in epidermal cells. Biochem Biophys Res Commun 410: 68-74, 2011.

12. Ryo A, Liou YC, Lu KP and Wulf G: Prolyl isomerase Pin1: a catalyst for oncogenesis and a potential therapeutic target in cancer. J Cell Sci 116: 773-783, 2003.

13. Hennig L, Christner C, Kipping M, et al: Selective inactivation of parvulin-like peptidyl-prolyl cis/trans isomerases by juglone. Biochemistry 37: 5953-5960, 1998.

14. Rippmann JF, Hobbie S, Daiber C, et al: Phosphorylationdependent proline isomerization catalyzed by Pin1 is essential for tumor cell survival and entry into mitosis. Cell Growth Differ 11: 409-416, 2000.

15. Chao SH, Greenleaf AL and Price DH: Juglone, an inhibitor of the peptidyl-prolyl isomerase Pin1, also directly blocks transcription. Nucleic Acids Res 29: 767-773, 2001.

16. He J, Lau AG, Yaffe MB and Hall RA: Phosphorylation and cell cycle-dependent regulation of $\mathrm{Na}^{+} / \mathrm{H}^{+}$exchanger regulatory factor-1 by Cdc2 kinase. J Biol Chem 276: 41559-41565, 2001.

17. Vivanco I and Sawyers CL: The phosphatidylinositol 3-kinase AKT pathway in human cancer. Nat Rev Cancer 2: 489-501, 2002.

18. Di Cristofano A, Kotsi P, Peng YF, Cordon-Cardo C, Elkon KB and Pandolfi PP: Impaired Fas response and autoimmunity in $\mathrm{Pten}^{+/-}$mice. Science 285: 2122-2125, 1999.

19. Chang F, Lee JT, Navolanic PM, et al: Involvement of PI3K/ Akt pathway in cell cycle progression, apoptosis, and neoplastic transformation: a target for cancer chemotherapy. Leukemia 17: 590-603, 2003

20. Testa JR and Bellacosa A: AKT plays a central role in tumorigenesis. Proc Natl Acad Sci USA 98: 10983-10985, 2001.

21. Huang C, Schmid PC, Ma WY, Schmid HH and Dong Z: Phosphatidylinositol-3 kinase is necessary for 12-O-tetradecanoylphorbol-13-acetate-induced cell transformation and activated protein 1 activation. J Biol Chem 272: 4187-4194, 1997.

22. Kang NJ, Lee KW, Lee DE, et al: Cocoa procyanidins suppress transformation by inhibiting mitogen-activated protein kinase kinase. J Biol Chem 283: 20664-20673, 2008.

23. Kim JE, Son JE, Jung SK, et al: Cocoa polyphenols suppress TNF-alpha-induced vascular endothelial growth factor expression by inhibiting phosphoinositide 3-kinase (PI3K) and mitogen-activated protein kinase kinase-1 (MEK1) activities in mouse epidermal cells. Br J Nutr 104: 957-964, 2010.

24. Urusova DV, Shim JH, Kim DJ, et al: Epigallocatechin-gallate suppresses tumorigenesis by directly targeting Pin1. Cancer Prev Res (Phila) 4: 1366-1377, 2011.

25. Aithal BK, Sunil Kumar MR, Rao BN, et al: Evaluation of pharmacokinetic, biodistribution, pharmacodynamic, and toxicity profile of free juglone and its sterically stabilized liposomes. J Pharm Sci 100: 3517-3528, 2011. 
26. Lee KM, Lee DE, Seo SK, et al: Phosphatidylinositol 3-kinase, a novel target molecule for the inhibitory effects of kaempferol on neoplastic cell transformation. Carcinogenesis 31: 1338-1343, 2010.

27. Baselga J: Targeting the phosphoinositide-3 (PI3) kinase pathway in breast cancer. Oncologist 16 (Suppl 1): S12-S19, 2002.

28. Nomura M, He Z, Koyama I, Ma WY, Miyamoto K and Dong Z: Involvement of the Akt/mTOR pathway on EGF-induced cell transformation. Mol Carcinog 38: 25-32, 2003.

29. Liu G, Bode A, Ma WY, Sang S, Ho CT and Dong Z: Two novel glycosides from the fruits of Morinda citrifolia (noni) inhibit AP-1 transactivation and cell transformation in the mouse epidermal JB6 cell line. Cancer Res 61: 5749-5756, 2001.

30. Barragan M, Bellosillo B, Campas C, Colomer D, Pons G and Gil J: Involvement of protein kinase $C$ and phosphatidylinositol 3-kinase pathways in the survival of B-cell chronic lymphocytic leukemia cells. Blood 99: 2969-2976, 2002.

31. Kassenbrock CK, Hunter S, Garl P, Johnson GL and Anderson SM: Inhibition of Src family kinases blocks epidermal growth factor (EGF)-induced activation of Akt, phosphorylation of c-Cbl, and ubiquitination of the EGF receptor. J Biol Chem 277: 24967-24975, 2002.

32. Kim EH, Na HK, Kim DH, et al: 15-Deoxy-Delta12,14prostaglandin $\mathrm{J} 2$ induces COX-2 expression through Akt-driven AP-1 activation in human breast cancer cells: a potential role of ROS. Carcinogenesis 29: 688-695, 2008.

33. Aggarwal BB and Shishodia S: Molecular targets of dietary agents for prevention and therapy of cancer. Biochem Pharmacol 71: 1397-1421, 2006.

34. Vlahos CJ, Matter WF, Hui KY and Brown RF: A specific inhibitor of phosphatidylinositol 3-kinase, 2-(4-morpholinyl)-8-phenyl-4H1-benzopyran-4-one (LY294002). J Biol Chem 269: 5241-5248, 1994.

35. Cross MJ, Stewart A, Hodgkin MN, Kerr DJ and Wakelam MJ: Wortmannin and its structural analogue demethoxyviridin inhibit stimulated phospholipase A2 activity in Swiss 3T3 cells. Wortmannin is not a specific inhibitor of phosphatidylinosito 3-kinase. J Biol Chem 270: 25352-25355, 1995.

36. Gruda MC, Kovary K, Metz R and Bravo R: Regulation of Fra-1 and Fra-2 phosphorylation differs during the cell cycle of fibroblasts and phosphorylation in vitro by MAP kinase affects DNA binding activity. Oncogene 9: 2537-2547, 1994.
37. Oehler T, Pintzas A, Stumm S, Darling A, Gillespie D and Angel P: Mutation of a phosphorylation site in the DNA-binding domain is required for redox-independent transactivation of AP1-dependent genes by v-Jun. Oncogene 8: 1141-1147, 1993.

38. Pulverer BJ, Kyriakis JM, Avruch J, Nikolakaki E and Woodgett JR: Phosphorylation of c-jun mediated by MAP kinases. Nature 353 670-674, 1991.

39. Kim JA, Lee EK, Park SJ, et al: Novel anti-cancer role of naphthazarin in human gastric cancer cells. Int J Oncol 40: 157-162, 2011.

40. Liu L, Li W, Koike K, Zhang S and Nikaido T: New alpha-tetralonyl glucosides from the fruit of Juglans mandshurica. Chem Pharm Bull (Tokyo) 52: 566-569, 2004.

41. Kamei H, Koide T, Kojima T, Hashimoto Y and Hasegawa M: Inhibition of cell growth in culture by quinones. Cancer Biother Radiopharm 13: 185-188, 1998.

42. Schwartz MA and Baron V: Interactions between mitogenic stimuli, or, a thousand and one connections. Curr Opin Cell Biol 11: 197-202, 1999.

43. Cantley LC: The phosphoinositide 3-kinase pathway. Science 296: 1655-1657, 2002.

44. Datta SR, Brunet A and Greenberg ME: Cellular survival: a play in three Akts. Genes Dev 13: 2905-2927, 1999.

45. Vogt PK: Jun, the oncoprotein. Oncogene 20: 2365-2377, 2001.

46. Subbaramaiah K, Norton L, Gerald W and Dannenberg AJ Cyclooxygenase-2 is overexpressed in HER-2/neu-positive breast cancer: evidence for involvement of AP-1 and PEA3. J Biol Chem 277: 18649-18657, 2002.

47. Subbaramaiah K, Lin DT, Hart JC and Dannenberg AJ: Peroxisome proliferator-activated receptor gamma ligands suppress the transcriptional activation of cyclooxygenase-2. Evidence for involvement of activator protein-1 and CREB-binding protein/ p300. J Biol Chem 276: 12440-12448, 2001.

48. Guo YS, Hellmich MR, Wen XD and Townsend CM Jr: Activator protein-1 transcription factor mediates bombesin-stimulated cyclooxygenase- 2 expression in intestinal epithelial cells. J Biol Chem 276: 22941-22947, 2001.

49. Evans JF and Kargman SL: Cancer and cyclooxygenase-2 (COX-2) inhibition. Curr Pharm Des 10: 627-634, 2004.

50. Walker EH, Pacold ME, Perisic O, et al: Structural determinants of phosphoinositide 3-kinase inhibition by wortmannin, LY294002, quercetin, myricetin, and staurosporine. Mol Cell 6: 909-919, 2000. 